\author{
ACTA MYCOLOGICA \\ Vol. 46 (1): 75-81 \\ 2011
}

\title{
A new record of the rare earthstar Geastrum berkeleyi from the Świętokrzyskie Mts
}

\author{
JUSTYNA JAWORSKA \\ Department of Botany, Institute of Biology, Jan Kochanowski University \\ Świętokrzyska 15, PL-25-406 Kielce, j.jaworska.kielce@gmail.com
}

Jaworska J.: A new record of the rare earthstar Geastrum berkeleyi from the Świętokrzyskie Mts. Acta Mycol. 46 (1): 75-81, 2011.

The article presents the third record of Geastrum berkeleyi Massee in Poland. For a long time the only known Polish locality of the species was in Kobylnica near Poznań, where G. berkeleyi was recorded in 1934. The fungus was found for the second time as recently as 2007 in Rąbiń (Kościan County). In 2009 this earthstar species was recorded in Milechowy reserve near Chęciny, in the western part of the Świętokrzyskie Mts (square ATPOL Ee 72). In the last mentioned locality, fruit-bodies of this rare fungus were recorded in a thermophilous forest habitats and also in a xerothermic anthropogenic shrublands, on a sandy calcareous soil. A comparison of diagnostic features of Geastrum berkeleyi var. berkeleyi and G. berkeleyi var. continentale is also given.

Key words: distribution, macrofungi, Milechowy reserve, Poland

\section{INTRODUCTION}

The genus Geastrum is represented in Poland by 17 species (Wojewoda 2003). Considering a characteristic morphological structure of fruitbodies they are relatively easy to recognize. Differences between particular species concern above all the sizes of fruitbodies, the shape of an exoperidium, the means in which an endoperidial body is attached to the exoperidium, the structure of a peristome, the habitat requirements and some microscopic features, especially the structure and the size of basidiospores.

All species of the genus Geastrum are either rare or very rare and only a few, such as Geastrum quadrifidum DC.: Pers., G. rufescens Pers., G. fimbriatum Fr. and G. minimum Schwein. can be considered as relatively frequently occurring. Since 2004 all species of this genus are strictly protected in Poland (Rozporządzenie 2004). 


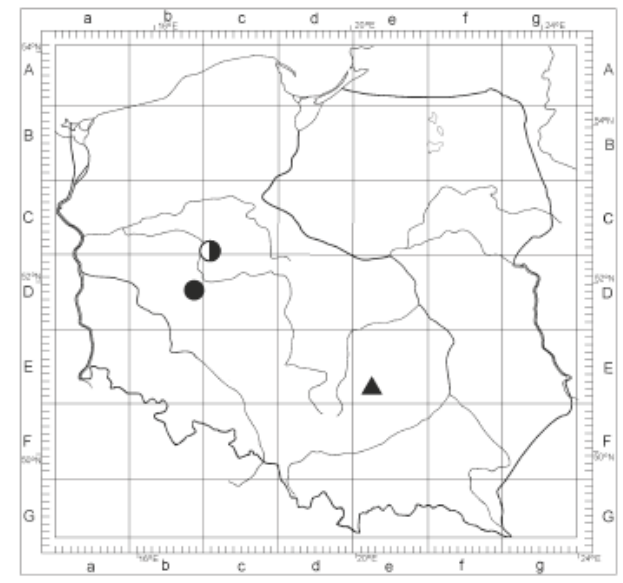

Fig. 1. Localities of Geastrum berkeleyi in Poland ( $\boldsymbol{\Lambda}$ - new locality, $\bullet$ - presently existing locality, $\mathbf{O}$ - extinct locality).

Among described earthstars particular attention deserves a very rare Geastrum berkeleyi, which was originally described from Great Britain (Massee 1889). It belongs to the most valuable mycobiota components in Poland, where until now it has been known only from two localities. The first locality was recorded in 1934 in Kobylnica near Poznań (Teodorowicz 1939) and the second one - in 2007 near Rąbiń, in the agricultural landscape of the General Dezydery Chłapowski Landscape Park (Kujawa 2009; Kujawa, Gierczyk 2010). In 2009 it was found for the third time in Milechowy reserve near Chęciny in the western part of the Świętokrzyskie Mts (Chęciny Region). The locality is: ATPOL network, square Ee 72 (Fig. 1).

\section{MATERIAL AND METHODS}

Investigations encompassed field observations and fruit-bodies collection, which subsequently were dried in the laboratory condition. The description of macroscopic features is based on fresh and dried material, on collection, comprising 5 fruitbodies in all stages of development. The microcharacters of one recorded (mature) fruit-body were observed and measured under a light microscope at magnification $\times 1250$. Measurements of basidiospores and threads of capillitium were performed using an ocular micrometer. Reported size of basidiospores and width of capillitium hyphae, were based on 22 and 5 measurements, respectively.

To illustrate the floristic composition and community structure of the habitat where Geastrum berkeleyi was found, phytosociological records were performed using Braun-Blanquet (1964) method. The nomenclature of vascular plants follows Mirek et al. (2002), and that of bryophytes is after Ochyra et al. (2003). 


\section{RESULTS}

\section{SPECIES DESCRIPTION}

\section{Geastrum berkeleyi Massee}

Annals of Botany 4: 79.1889 (as Geaster) (syn.: Geastrum pseudostriatum Hollós (1901), Geastrum hollosii V.J. Staněk (1958)

Systematic arrangement: Geastraceae, Lycoperdales, Gastromycetes (Jülich 1984); Lycoperdales, Basidiomycetes (Rudnicka-Jezierska 1991); Lycoperdales, Basidiomycetes, Basidiomycota (Hawksworth et al. 1995); Lycoperdales, Hymenomycetidae, Hymenomycetes, Basidiomycota (Sunhede 1997); Phallales, Agaricomycetidae, Basidiomycetes, Basidiomycota (Kirk et al. 2001); Geastrales, Phallomycetidae, Agaricomycetes, Basidiomycota, Fungi (Kirk et al. 2008).

Fruit-bodies typical for genus Geastrum. Immature fruit-bodies are closed and subglobose, 1-3.5 (4) cm in diameter. Exoperidium consists of three layers, and in the unexpanded fruit-bodies closely invests endoperidium. The exterior surface of young basidioma covered with plant debris and soil particles held by the adnate, light ochre-brown and sometimes rose tinged mycelial layer. As the fruit-bodies ripens the mycelial coating tends to flake away and the smooth, not shiny fibrillar layer is uncovered. Exoperidium splits open from the tip to about the middle in a stellate fashion divided into 4-10 triangular flaps (6-7 flaps in the specimens collected in Milechowy reserve). Due to swelling of pseudoparenchymal cells of exoperidium, the triangular flaps curve outwards and make contact with the soil, lifting the inner endoperidial layer of fruit-bodies into the air (Fig. $2)$. In such cases the flaps diameter reaches $4-10 \mathrm{~cm}$. The inner, fleshy layer of exoperidium is breakable and redish-brown or ochre coloured. Endoperidium globose or slightly flattened, usually has diameter from 1 to $3 \mathrm{~cm}$ and it is seated upon a short but broad pedicel, which can be usually clearly seen only in dried specimens. Indistinct apophysis is present, but also is frequently clearly seen in dry specimens only. Endoperidium is ochre-brown, dark brown, grey-brown coloured, and in older fruit-bodies is grey in colour. Its surface is coarsely verrucose, except for a smooth, circular area surrounding peristome. Peristome conical, distinctly plicate with about $15-18$ folds, grey-brown to brown. Its opening is crest-like frayed or bluntly ended.

Gleba dark brown when mature with chocolate tinge at times. Capillitial hyphae yellow-brown, unbranched, up to $13 \mu \mathrm{m}$ thick. Basidiospores globose, distinctly verrucose, olivaceous-brown (in $\mathrm{H}_{2} 0$, KOH) (Fig. 3), 4.75-6.10 $\mu \mathrm{m}$ in diameter. Spores measurements for this species given by different authors are:

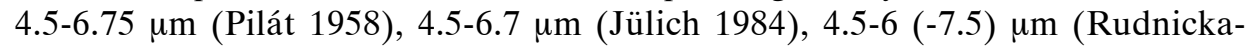
Jezierska 1991), 5.5-7 $\mu \mathrm{m}$ (Hansen, Knudsen 1997). The sizes of investigated spores from the fruit-bodies found in Milechowy reserve are close to those given by the above authors.

MATERiAl EXAMINED. Świętokrzyskie Mts Milechowy reserve near Chęciny, ca $230 \mathrm{~m}$ a.s.l.: in young planted pine forest, on sandy, calcareous soil, 07.09.2009.

The collected specimens have been deposited in the Fungarium of the Mathematics and Nature Faculty, Jan Kochanowski University, Kielce (KTC 4305). 


\section{TAXONOMICAL REMARKS.}

Geastrum berkeleyi is well characterized by arched, nonhygroscopic exoperidial flaps, clearly roughened - coarsely verrucose endoperidium, and distinctly plicate, conical peristome. Macromorphological features of the examined specimens are in good agreement with the previous description of $G$. berkeleyi (e.g., Rudnicka-Jezierska 1991). Also micromorphological characteristics correspond to those given in mycological literature, although it is worth emphasizing here that various authors have reported different measurements of spores, i.e.: 4.5-6.75 $\mu \mathrm{m}$ (Pilát 1958), 4.5-6.7

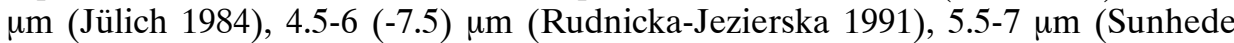
1997). Staněk (1958) distinguished two varieties of Geastrum berkeleyi, typical - var. berkeleyi Massee and var. continentale V.J. Staněk. Both varieties differ from each other in the following features: apophysis appearance, nature of ornamentation of basidiospores, and width of capillitial hyphae (Tab. 1). Fruit-bodies collected in the Milechowy reserve correspond to the descripition of $G$. berkeleyi var. continentale in this respect.

Geastrum berkeleyi shows particular similarities to a few other species belonging to this genus. G. campestre Morgan. (syn. G. pedicellatum (Batsch) Dörfelt \& Müll.-Uri), G. kotlabae V.J. Staněk and G. pectinatum Pers.: Pers. are the other taxa having a plicate, conical peristomes and except for the third mentioned mealy covered or rough surface of endoperidia. However, G. campestre is marked by its hygroscopic rays, more persistent pseudoparenchymatous layer of the exoperidium and smaller fruit-bodies (usually $6-20 \mathrm{~mm}$ in diameter) as well. G. kotlabae is also distinguished from $G$. berkeleyi by its strongly hygroscopic rays and more persistent pseudoparenchymatous layer of the exoperidium as well as additionally by the sessily seated endoperidial bodies. The surface of exoperidial bodies of G. kotlabae is also somewhat different. It is farinose in young fruit-bodies, and usually glabrous in older basidiomata. The features differentiating G. pectinatum from $G$. berkeleyi can mainly be seen in the morphology of pedicel and apophysis. G. pectinatum is characterized by having a long pedicel, and usually radially wrinkled - sulcate or striate apophysis, while the pedicel of G. berkeleyi is low and broad, and the apophysis is smooth. Also, G. pectinatum differs from G. berkeleyi in smooth surface of endoperidium.

Table 1

Comparison of diagnostic features of Geastrum berkeleyi var. berkeleyi and $G$. berkeleyi var. continentale

\begin{tabular}{|l|l|l|}
\hline \multicolumn{1}{|c|}{ Feature } & Geastrum berkeleyi var. berkeleyi & \multicolumn{1}{|c|}{$\begin{array}{c}\text { Geastrum berkeleyi var. } \\
\text { continentale }\end{array}$} \\
\hline Apophysis & $\begin{array}{l}\text { weakly developed (poorly } \\
\text { visible) }\end{array}$ & well developed \\
\hline Width of capillitial hyphae & up to $13 \mu \mathrm{m}$ & does not exceed $10.5 \mu \mathrm{m}$ \\
\hline Spores & $\begin{array}{l}\text { spherical, up to } 6 \mu \mathrm{m} \text { in } \\
\text { diameter }\end{array}$ & spherical, $4.5-6.2 \mu \mathrm{m}$ \\
\hline Ornamentation of spores & $\begin{array}{l}\text { up to } 15 \text { verrucae along the } \\
\text { circumference }\end{array}$ & $\begin{array}{l}12-16 \text { verrucae along the } \\
\text { circumference }\end{array}$ \\
\hline
\end{tabular}



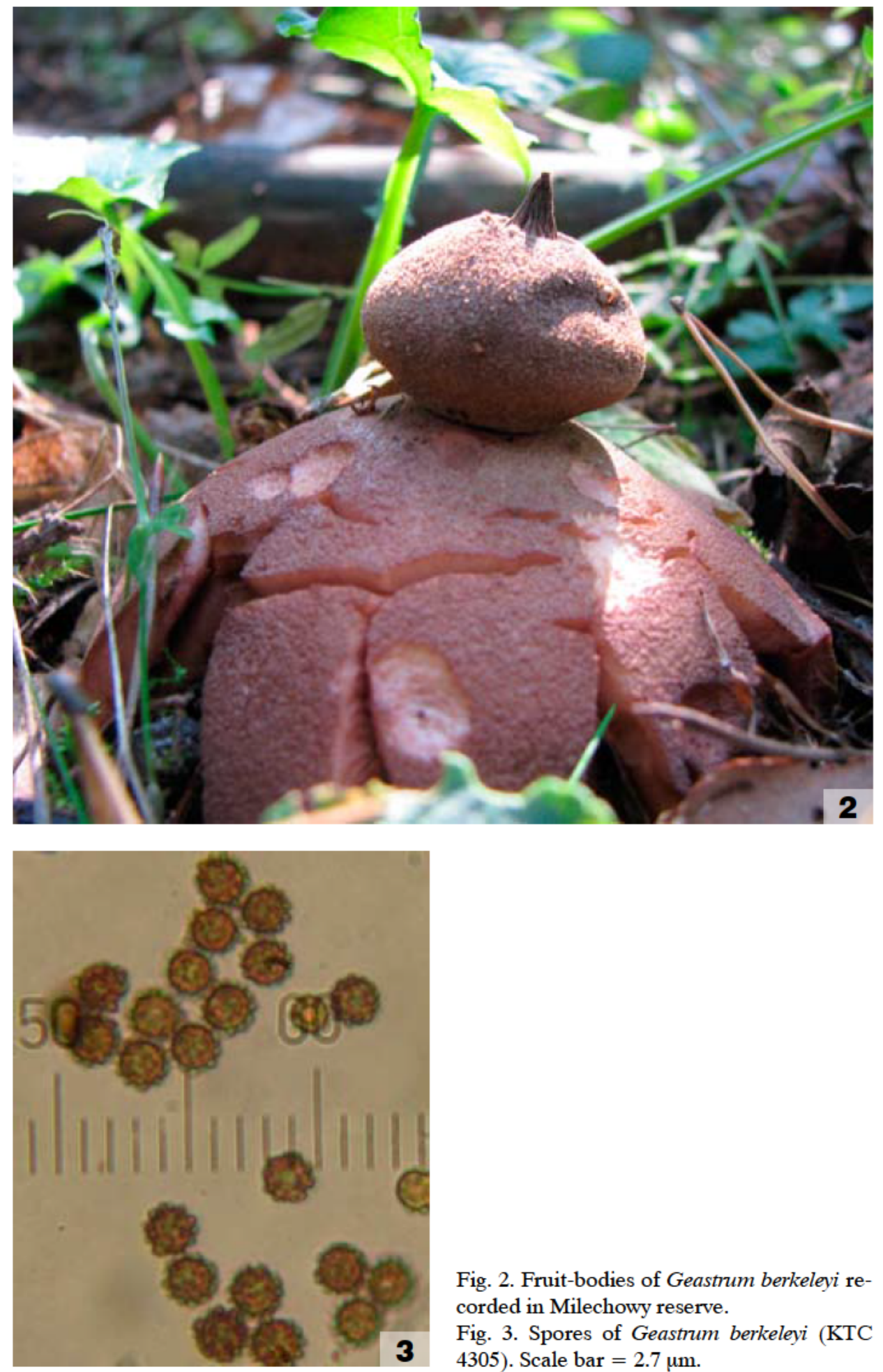

Fig. 2. Fruit-bodies of Geastrum berkeleyi recorded in Milechowy reserve.

Fig. 3. Spores of Geastrum berkeleyi (KTC 4305). Scale bar $=2.7 \mu \mathrm{m}$. 


\section{GENERAL DISTRIBUTION AND ECOLOGY}

Geastrum berkeleyi is a rare species. It is known from sparse locations in Asia and Europe. In Asia it has been reported from Japan and China (Kasuya et al. 2009). In Europe G. berkeleyi occurs in a dozen or so countries, including Austria, the Czech Republic, Denmark, Estonia, France, Germany, Great Britain, Hungary, the Netherlands, Poland, Slovakia, Spain, Sweden and Turkey (Arnolds, Veerkamp 2008; GBIF 2009; Dörfelt 1985; Honorubia et al. 1980; Jülich 1984; Lilleleht 1998; Lizoň 2001; Sunhede 1989, 1997).

In most European countries where the species was noted it appears on the "red lists" of threatened fungi: in Austria is listed as endangered by extinction (" 1 " category), in the Czech Republic and Denmark as critically endangered ("CR" and "E" category), in Estonia as vulnerable ("V" category), in Germany as a rarity ("R" category), in the Netherlands as susceptible and rare ("GE(z)" category), in Slovakia as vulnerable ("VU" category) and in Great Britain and Sweden as endangered ("EN" category) (Evans 2006; Wojewoda 2003). Geastrum berkeleyi was considered to be "extinct and probably extinct" in the last edition of the "Red list of macrofungi in Poland" (Wojewoda, Ławrynowicz 1992, 2006). Certainly, the species is not extinct in Poland. Currently, it occurs at least in two localities in the area and therefore the status of the taxon should be changed to endangered.

The detailed ecology of G. berkeleyi in Northern Europe was addressed by Sunhede (1989). Other valuable data on the ecology of the earthstar in Europe were also provided by Staněk (1958), Dörfelt (1985) and Kreisel (1987). According to these authors, $G$. berkeleyi occurs mostly on sun-warm sites, in coniferous and deciduous forests, groves and tree plantations (with Picea, Pinus, Acer, Carpinus, Corylus, Crataegus, Fagus, Fraxinus, Juniperus, Prunus, Quercus and Tilia), on well drained, base-rich ground, especially on calcareous soils. It is also known from pine and xerothermic shrubs, Syringa-shrubberies and open sites. Most finds of fresh fruit-bodies of the species have been made in September and October, but records from the end of August and beginning of December are also known. Basidocarps of G. berkeleyi can grow scattered or in clusters, sometimes in bows or fairy rings (Sunhede 1989).

Until now $G$. berkeleyi was reported from two various habitats in Poland, i.e.: from a margin of spruce grove (Teodorowicz 1939) and a riparian ash forest with undercrop of Crataegus and Prunus (Kujawa, Gierczyk 2010). The new, presented here locality of $G$. berkeleyi recorded in Milechowy reserve was observed on sandy, calcareous soil in thermophilous forest habitat.

The floristic composition of the plant habitat, in which several fruit-bodies of the species were found is as follow: tree layer with $70 \%$ density, shrub layer with $15 \%$ density, herb layer with $40 \%$ cover, moss layer with $30 \%$ cover.

The tree layer consists only of Pinus sylvestris (4.4). In the shrub layer occur: Lonicera xylosteum (1.1), Quercus petraea (1.2), Juniperus communis (1.1), Carpinus betulus (+). In the herb layer mainly occur: Festuca rubra (3.1), Fragaria vesca (1.1), Hieracium pilosella (+.2), Thymus serpyllum (1.2), Chimaphila umbellata (1.1), Melampyrum pratense (2.2), Vaccinium myrtillus $(+.2)$, Galium mollugo $(+.2)$, Veronica officinalis (1.1). The moss layer is represented mostly by Entodon schreberi (3.1) and Hylocomium splendens (3.1). 
Acknowledgements. I’m very grateful to Prof. Janusz Łuszczyński and Prof. Andrzej Massalski for helpful discussion and comments on the manuscript.

\section{REFERENCES}

Arnolds E., Veerkamp M. 2008. Basisrapport Rode Lijst Paddenstoelen. Nederlandse Mycologische Vereniging, Utrecht, $295 \mathrm{pp}$.

Braun-Blanquet J. 1964. Pflanzensoziologie. Wien-New York.

Dörfelt H. 1985. Die Erdsterne: Geastraceae und Asteraceae. Die Neue Brehm-Bücherei, A. Ziemsen Verlag, Wittenberg, $108 \mathrm{pp}$.

Evans S. 2006. The red data list of threatened British fungi: a preliminary assessment (Version 1.0). British Mycological Society: Published on the WEB site: http://www. fieldmycology.net/Download/ [Accessed: 11-2010].

GBIF 2009. Biodiversity occurrence data provided by: Steiermärkisches Landesmuseum Joanneum Herbarium GJO, University of Vienna, Institute for Botany - Herbarium WU (Accessed through GBIF Data Portal, data.gbif.org, 2009-11-02).

Hawksworth D.L., Kirk P.M., Sutton B.C., Pegler D. 1995. Ainsworth \& Bisby's Dictionary of the Fungi. $8^{\text {th }}$ ed. Intern. Mycol. Inst., University Press, Cambridge, 616 pp.

Honrubia García M., Calonge F.d.D., Demoulin V., Moreno G., Llimona X. 1980. Aportación al conocimiento de los hongos del SE. de España VI: Esclerodermatales Lycoperdales, Nidulariales, Phallales, Hymenogasterales, Podoxales (Gasteromycetes, Basidiomycetes). Anales de la Universidad de Murcia: Ciencias 38 (1/4): 101-132.

Index Fungorum. 2009. Published on the WEB site: http://www. indexfungorum.org/Names/Names.asp [Accessed: 11-2009].

Jülich W. 1984. Die Nichtblätterpilze, Gallertpilze und Bauchpilze. Aphyllophorales, Heterobasidiomycetes, Gastromycetes. (In:) H. Gams (ed.). Kleine Kryptogamenflora IIb/1. Basidiomyceten. VEB G. Fischer Verl., Jena.

Kasuya T., Yamamoto Y., Sakamoto H., Seiji T., Hoshino T., Kobayashi T. 2009. Floristic study of Geastrum in Japan: three new records for Japanese mycobiota and reexamination of the authentic specimen of Geastrum minus reported by Sanshi Imai. Mycoscience, 50: 84-93.

Kirk P.M., Cannon P.F., David J.C., Stalpers J.A. (eds). 2001. Ainsworth \& Bisby's Dictionary of the Fungi, $9^{\text {th }}$ ed. CABI, Wallingford, $655 \mathrm{pp}$.

Kirk P.M., Cannon P. F., Minter D. W., Stalpers J. A. (eds). 2008. Ainsworth \& Bisby's Dictionary of the Fungi, $10^{\text {th }}$ ed. CABI, Wallingford, $759 \mathrm{pp}$.

Kreisel H. (ed.). 1987. Pilzflora der Deutschen Demokratischen Republik. Basidiomycetes (Gallert-, Hutund Bauchpilze). VEB G. Fischer Verl., Jena, 281 pp.

Kujawa A. 2009. Macrofungi of wooded patches in the agricultural landscape. I. Species diversity. Acta Mycol. 44 (1): 49-75.

Kujawa A., Gierczyk B. 2010. Rejestr gatunków grzybów chronionych i zagrożonych w Polsce. III. Wykaz gatunków przyjętych do rejestru w roku 2007. Przegląd Przyrodniczy 21 (1): 8-53.

Lilleleht V. (ed). 1998. Eesti punane raamat (Estonian red data book). Eesti Teaduste Akadeemia Looduskaitse Komisjon, Tartu, 150 pp.

Lizoň P. 2001. Červený zoznam húb Slovenska 3. Verzia. December 2001. (In:) D. Baláž, K. Marhold, P. Urban (eds). Červený zoznam rastlín a živo íchov Slovenska. Ochrana Prírody 20. (supplement): 6-13.

Massee G. 1889. A monograph of the British Gasteromycetes. Annals of Botany 4: 1-103.

Mirek Z., Piękoś-Mirkowa H., Zając M. 2002. Flowering plants and pteridophytes of Poland - a checklist. (In:) Z. Mirek (ed.). Biodiversity of Poland 1. W. Szafer Institute of Botany, Polish Academy of Sciences, Kraków, 442 pp.

Ochyra R., Żarnowiec J., Bednarek-Ochyra H. 2003. Census Catalogue of Polish Mosses. Katalog mchów Polski. (In:) Z. Mirek (ed.). Biodiversity of Poland 3. W. Szafer Institute of Botany, Polish Academy of Sciences, Kraków, 372 pp.

Pilát A. 1958. (ed.). Gasteromycetes - Houby - břichatky. Flora ČSR, ser. B. 1. Nakl. Československé Akademie Věd, Praha: 392-526.

Rozporządzenie 2004. Rozporządzenie Ministra Środowiska z dnia 9 lipca 2004 r. w sprawie gatunków dziko występujących grzybów objętych ochroną. Dz. U. Nr 168 (2004), poz. 1765. 
Rudnicka-Jezierska W. 1991. Flora Polska. Grzyby (Mycota). 23. Purchawkowe (Lycoperdales), Tęgoskórowe (Sclerodermatales), Pałeczkowe (Tulostomatales), Gniazdnicowate (Nidulariales), Sromotnikowe (Phallales), Osiakowe (Podaxales). Instytut Botaniki PAN, Kraków, 210 pp.

Staněk V.J., 1958. Čeled Geastraceae - Hvězdovhovité. (In:) A. Pilát (ed.). Gasteromycetes - Houby břichatky. Flora ČSR, ser. B. 1. Československé Akademie Věd, Praha: 392-526.

Sundhede S. 1989. Geastraceae (Basidiomycotina). Morphology, ecology, and systematics with special emphasis on the North European species. Synopsis Fungorum. 1. Fungiflora A/S, Oslo, 534 pp.

Sunhede S. 1997. Geastrum Pers.: Pers. (In:) L.Hansen, H. Knudsen (eds). Nordic macromycetes. 3. Heterobasidioid, aphyllophoroid and gastromycetoid Basidiomycetes: 341-435.

Teodorowicz F. 1939. Nowe dla flory polskiej podrzędy, rodziny, rodzaje i gatunki wnętrzniaków (Gasteromycetes). Kosmos 64 (1): 83-107.

Wojewoda W. 2003. Checklist of Polish larger Basidiomycetes. Krytyczna lista wielkoowocnikowych grzybów podstawkowych Polski. (In:) Z. Mirek (ed.). Biodiversity of Poland 7. W. Szafer Institute of Botany, Polish Academy of Sciences, Kraków, 812 pp.

Wojewoda W., Ławrynowicz M. 1992. Czerwona lista grzybów wielkoowocnikowych zagrożonych w Polsce. Red list of threatened macrofungi in Poland. (In:) K. Zarzycki, W. Wojewoda, Z. Heinrich (eds). Lista roślin zagrożonych w Polsce (wyd. 2). List of threatened plants in Poland (2 ${ }^{\text {nd }}$ ed.). W. Szafer Institute of Botany, Polish Academy of Sciences, Kraków: 27-56.

Wojewoda W., Lawrynowicz M. 2006. Red list of the macrofungi in Poland. Czerwona lista grzybów wielkoowocnikowych w Polsce. (In:) Z. Mirek, K. Zarzycki, W. Wojewoda, Z. Szeląg (eds). Red list of plants and fungi in Poland. W. Szafer Institute of Botany, Polish Academy of Sciences, Kraków: 53-70.

\section{Nowe stanowisko rzadkiego gwiazdosza Geastrum berkeleyi z Gór Świętokrzyskich}

\section{Streszczenie}

W Polsce dotychczas znane były tylko 2 stanowiska Geastrum berkeleyi. Po raz pierwszy znaleziono go w roku 1934 w Kobylnicy koło Poznania (Teodorowicz 1939). Jego drugie stanowisko stwierdzono w 2007 r. w Rąbinie w Województwie Wielkopolskim (Kujawa 2009; Kujawa, Gierczyk 2010). W 2009 r. znaleziony został w rezerwacie Milechowy koło Chęcin, w zachodniej części Gór Świętokrzyskich. Jest to trzecie jego znane stanowisko w Polsce. Ten rzadki gatunek występuje w ciepłych lasach, często pochodzenia antropogenicznego oraz w kserotermicznych zaroślach i na piaszczystych glebach wapiennych. Gatunek znany w Europie i Azji.

W Europie odnotowano jego występowanie w Austrii, Republice Czeskiej, Danii, Estonii, Francji, Niemczech, Wielkiej Brytanii, Holandii, Słowacji, Hiszpanii, Szwecji, Turcji oraz na Węgrzech (Arnolds, Veerkamp 2008; GBIF 2009; Dörfelt 1985; Honorubia et al. 1980; Jülich 1984; Lilleleht 1998; Lizoň 2001; Sunhede 1989, 1997). W większości krajów należy do grzybów ujętych na czerwonych listach gatunków zagrożonych. 